\title{
Pojetí tacitních znalostí v paradigmatu sjednoceného pole ${ }^{1}$
}

\author{
Radim Šíp, Vlastimil Švec \\ Masarykova univerzita, Pedagogická fakulta, Katedra pedagogiky
}

Redakci zasláno 3. 6. 2013 / upravená verze obdržena 30. 9. 2013 / k uveřejnění přijato 1. 10. 2013

\begin{abstract}
Abstrakt: Cílem teoretické studie je vyjasnit pojetí tacitních znalostí (TZ). V první části autoři ukazují, v čem tkví hlavní problém současného diskurzu o tacitních znalostech. Jestliže budeme vnímat znalost jako mentální reprezentaci, nemůžeme náležitě pochopit a zkoumat TZ. Ve druhé části za pomocí příkladů z děl J. Deweyho a J. Piageta autoři dokládají, že zde již jedno století existuje alternativní - funkcionální pojetí znalosti. Třetí část se zaměřuje na definice znalosti a poukazuje na fakt, že problematika takových definic spočívá $\mathrm{v}$ tom, že pedagogové a epistemologové nerozhodně stojí mezi tradičním a alternativním paradigmatem (v textu pracovně nazývaných: „paradigma oddělených objektů“ a „paradigma sjednoceného pole“). To vede $\mathrm{k}$ mnohým nesrovnalostem $\mathrm{v}$ jednotlivých teoriích a $\mathrm{k}$ jejich malé použitelnosti v praxi. Ve čtvrté části autoři představují epistemologické pozadí tradičního paradigmatu, aby v části páté poskytli popis pozadí paradigmatu alternativního. Díky tomuto postupu jsou v závěrečné části autoři schopni definovat alternativní pojetí TZ. Docházejí zde ke zjištění, že znalost musíme vnímat jako dynamickou strukturu sjednoceného pole a TZ chápat jako tacitní dimenzi dynamické struktury (TDZ). Teprve takto pochopená tacitní znalost nám umožňuje zkoumat její dimenze.
\end{abstract}

Klíčová slova: znalosti, tacitní znalosti, paradigma oddělených objektů, paradigma sjednoceného pole, jednání, dynamická struktura

Tento text navazuje na naše dř́vější studie (Švec, 2012a, 2012b), v nichž byla představena problematika tacitních znalostí (dále TZ). TZ jsme s využitím současných literárních zdrojů charakterizovali jako individuální znalosti jedince, které vznikají na základě jeho zkušeností, jsou procedurální a obtížně navenek vyjádřitelné (Švec, 2012a, s. 387). Na základě řady teoretických i empirických studií jsme dále formulovali tezi, že TZ lze do určité míry sdílet (např v týmu expertů, ale i ve skupině začátečníků a zkušených odborníků), a to tím, že se jejich část zexplicitní, např. sebereflexí. Ve skupině si mohou

1 Studie byla finančně podpořena GA ČR v rámci řešení grantového projektu 13-200496 Osvojování tacitních znalostí studenty učitelství v průběhu jejich pedagogické praxe. 
jedinci vzájemně vyjasňovat významy obsahů svých reflexí a hledat jejich společné jádro (Švec, 2012b). Na druhé straně jsme se však opakovaně setkávali s konstatováním mnoha autorů, že TZ jsou hluboce zakotveny v mysli jedince a že je tedy velmi obtížné je zexplicitnit.

Při dalším, hlubším studiu problematiky tacitních znalostí jsme se postupně dobírali $\mathrm{k}$ informacím, které začaly proměňovat náš přístup $\mathrm{k} \mathrm{TZ}$, ale i ke znalostem obecně. Změnu našeho př́istupu k TZ se pokusíme objasnit v této studii. Opíráme se sice o filozofická východiska, avšak nepřekračujeme kontext tématu této studie. Nejdříve budeme rekapitulovat charakteristiky TZ, abychom se dostali k jejich problematickému jádru. S mírným předstihem zde prozradíme, že problematičnost $\mathrm{TZ}$ relativně věrně odráží situaci v celém pedagogickém diskurzu, který je neurčitě rozkročen mezi tradičním a alternativním (funkcionálním) způsobem myšlení. Ona neurčitost nese svůj negativní otisk napříč pedagogickou teorií, výzkumem i praxí. Vyjasnění této skutečnosti nám pomůže nově chápat znalost obecně a uvědomit si, co to přinese pro nové pochopení TZ a pro možnosti jejich výzkumu.

\section{V čem tkví problém současného pojetí tacitních znalostí}

Představa neuvědomovaných znalostí má velice staré kořeny, můžeme ji vysledovat až k Platónově anamnésis (rozvzpomínání). Podle tohoto mýtu si racionální duše rozvzpomíná na to, co již „zahlédla“ ve světě idejí. Nepodceňujeme platónské řešení záhady, jak je možné, že člověk poznává, přestože již $\mathrm{k}$ jakémukoli procesu poznání potřebuje mnoho předchozích znalostí či schopností. Avšak naše pojetí tacitnosti (implicitnosti) znalostí vychází z jiného zdroje. Nepojímáme totiž znalost jako „zření“ (idejí Platón, teoretických podobností - Aristotelés, esencí - moderní realisté), ale jako výsledek jednání v kontinuálně se proměňujícím prostředí. Proto pro nás tacitnost bude znamenat spíše tu dimenzi znalosti, která nám efektivně pomáhá $v$ řešení problémů, kterou si však nejsme schopni plně a bezprostředně uvědomit. Naše pojetí TZ má charakter něčeho nového, nepojímáme jej jako apriorní záležitost. Tedy jako to, co již předem čeká, až bude odhaleno - např jako u matematických pojmů, jestliže matematické vztahy chápeme jako rys skutečnosti a nikoli jako nástroj lidského jednání. ${ }^{2}$

\footnotetext{
Námi předkládané pojetí má velice blízko k Bergsonově filozofii a k významným zjištěním Merleau-Pontyho - nejen v jeho Fenomenologii vnímání, ale především v jeho Viditelném a neviditelném (srov. Meraleau-Ponty, 2004).
} 
Pojem TZ je spojen se jménem Michaela Polanyiho (1958/1962, 1966/1983), ${ }^{3}$ který vyslovil tezi, že víme více, než dovedeme říci (Polanyi, 1966/1983, s. 4). Polanyi však spíše uvažoval o dimenzích znalostí, které jsou sice osobní, ale přesahují do vnějšího prostředí. Rozlišil tacitní a explicitní dimenzi znalostí. Tacitní dimenze je výrazně osobní (souvisí s individualitou subjektu), je velmi obtížně (pokud vůbec) vyjádřitelná a nelze ji sdílet s ostatními subjekty. Explicitní dimenze je sice také osobní, je možné ji však vyjádřit slovy, čísly, obrázky nebo i zvuky a pohyby těla a lze ji tedy sdílet s druhými subjekty.

Polanyi chápal TZ (resp. tacitní dimenzi znalostí) více procesuálně, než se obecně soudí. Proto se zřejmě více přikláněl k pojmu tacit knowing. Vyslovil hypotézu, že během procesu utváření či uplatnění znalosti se tacitní dimenze neustále proměňuje, přičemž významnou úlohu sehrává naše tělo (Polanyi, 1966/1983): tělo je významný zdroj všech našich vnějších znalostí (s. 15), tělo zprostředkovává kontakt s vnějším prostředím (s. 16). Těmito myšlenkami Polanyi předbíhal svoji dobu a v mnohém spíše intuitivně cítil prosazující se proud nového, dynamického př́ístupu k chápání znalostí. Přesto i jeho koncepce zůstala $v$ hranicích tradičního myšlení. Z Polanyiho vyšlo mnoho autorů. $V$ jejich textech však stále více sílí tendence z tacitní dimenze utvořit specifický typ znalosti, který jako takový je „nevyslovený“. Již zde můžeme zaregistrovat jeden z projevů tzv. substantivizace ${ }^{4}$ jež nám předem podsouvá představu nějaké znalosti, kterou nelze vyjádřit, explikovat a která je tím oddělena od znalosti jiné, explikovatelné. Dimenze či aspekt (jak to budeme nazývat níže) se stává odlišnou entitou. Tak vzniká dichotomie tacitní (někdy nazývané implicitní) vs. explicitní, která se stává dogmatem velké většiny definic a charakteristik TZ. Panahiu, Watson a Partridge (2012) podávají přehled vlastností tacitních i explicitních znalostí, které se ve výčtech dalších autorů výslovně či nevýslovně opakují (viz tab. 1).

\footnotetext{
V tomto a v dalších př́ípadech, $\mathrm{v}$ nichž chceme zdůraznit dobu prvního vydání díla, uvádíme v odkaze i v seznamu literatury společně jak rok prvního vydání, tak rok vydání, z něhož citujeme. Např (1966/1983) znamená, že Polanyiho kniha The tacit dimension byla poprvé vydána v roce 1966 a my čerpáme z pozdějšího vydání z roku 1983.

4 Tomuto pojmu se budeme věnovat níže v části 2 . Zde jenom poznamenejme, že se jedná o tendenci, která z procesu, pro nějž je charakteristické slovesné vyjádření, utváří stav, který lze snadno vyjádřit podstatným jménem.
} 
Tabulka 1

Vlastnosti tacitních a explicitních znalostí:

\begin{tabular}{ll}
\hline Tacitní znalosti & Explicitní znalosti \\
\hline - uloženy v lidských myslích & • artikulované, strukturované, \\
- vysoce individualizované a osobní & dokumentované \\
- jsou nabývány prostřednictvím zkušeností & • jsou nabývány prostřednictvím instrukce, \\
- nestrukturované, obtížně se zviditelňují, & výkladu nebo opakování \\
hodnotí, formalizují, zkoumají, zachycují & - jednoduše se zkoumají, kodifikují, \\
- a komunikují & formalizují, shromažd'ují, sdílejí, \\
- neuvědomované znalosti & komunikují a užívají \\
& - mohou být uloženy v knihách, časopisech, \\
& databázích atd. \\
\hline
\end{tabular}

Pozn.: Převzato a upraveno dle Panahiu, Watson a Partridge (2012, s. 1096).

Na základě analýzy četných literárních pramenů dospěli k téměř shodným poznatkům McAdam, Mason a McCrory (2007). I často citovaný Sternberg (1999) došel k obdobnému výčtu, a i když přidává další vlastnosti, charakter TZ tím nijak nevyjasňuje (s. 231-234).

V tomto výčtu bychom mohli pokračovat. Podstatné je, že se ve výrazné většině textů opakuje zmíněná dichotomie. Někteří autoři pojmy „tacitní a „explicitní" chápou jako protilehlé body kontinuální úsečky: explicitní znalosti představují nízký stupeň tacitnosti, zatímco hluboce zakořeněné tacitní znalosti nesou vysoký stupeň tacitnosti (Ambrosini \& Bowman, 2001), avšak dále s touto kontinuálností nepracují. Zmíněné dichotomické napětí tak můžeme nalézt téměř ve většině dosavadních textů o TZ. Explicitní znalosti od tacitních (implicitních) odlišuje především skutečnost, že jsou artikulovatelné, kodifikovatelné, a tak prenositelné do vnějšího prostředí (je možné je dokonce uložit v knihách, $v$ diskurzech, databázích). Tuto vlastnost můžeme popsat jako snadnost procesu prevodu znalosti na poznatek (k tomu viz následující část studie).

Aby však k takové artikulovatelnosti mohlo dojít, musíme být schopni děje a procesy analyzovat na jednotlivé části a tyto části substantivizovat. $S u b$ stantivizací zde předběžně míníme proces, v němž vymezeným částem přisoudíme význam, který údajně odráží jejich podstatu. Tento význam podobně jako podstata části je vnímán jako neměnný. Tak je proces proměňován na sled diskrétních událostí, které mají relativně stálou povahu, a můžeme je proto explicitně komunikovat. Právě tato záměna procesu za stálost diskrét- 
ních částí je podstatou symbolizace, kterou jakýkoli kalkul či přirozený jazyk potřebuje ke svému fungování, nebot' kalkuly a jazyky, jestliže nadřazujeme jejich referenční funkci nad metaforickou, mají ze své podstaty atomistický charakter. Pojmy jazyka musí být diskrétní, musí mít jasné hranice významu.

S představou artikulovatelnosti a komunikovatelnosti explicitních znalostí a neartikulovatelnosti a složité komunikovatelnosti TZ se dostáváme $\mathrm{k}$ důležitému tématu: k problematice sdílení znalostí mezi subjekty. Tato problematika nejvíce charakterizuje tradiční způsob uvažování. V této tradiční optice jsou znalosti něčím, co vzniká uvnitř jedince a co je teprve posléze komunikováno a konfrontováno se „stejnou“ (resp. obdobnou) znalostí ostatních. Takový obecný přístup ke znalosti však zcela komplikuje pochopení TZ, nebot' tyto znalosti jsou z podstaty svých definic obtížně artikulovatelné, a je tedy složité je sdílet.

Snahu o překročení hranice mezi subjekty můžeme cítit v některých textech, které se snaží uchopit problematiku TZ lépe, než to učinila většina pokračovatelů Polanyiho. Zajímavým př́íkladem je Castillova (2002) typologie, kde ve výčtu typů TZ vedle „silně osobních“ najdeme také TZ „sociokulturní“, které „nejsou vázány na osobu jednoho subjektu“, a dále také tzv. „sémantické“ TZ, které „jsou přítomny v myslích subjektů dané odborné komunity“ (Castillo, 2002, s. 48-52). V př́padě „sociokulturních“ či „sémantických“ TZ jsou v prostoru mezi subjekty znalosti sdíleny a rozvíjeny, ale předtím a poté jsou na „tacitní úrovni“ uchovávány v jednotlivých subjektech (v jejich hlavách). Jak se však vyrovnat s tím, že se znalosti generují a uchovávají v jednotlivých subjektech, $v$ jejich hlavách a přitom je možné je posléze intersubjektivně sdílet a rozvíjet, aby se nakonec opět vrátily zpět do subjektů a tam byly „tacitně“ přítomny a čekaly na své vyvolání a použití?

Tento zdánlivě neřešitelný paradox, je řešitelný pouze změnou optiky, která nás nutí vidět věci pouze jedním způsobem. Na obecnou podstatu podobných paradoxů nás upozorňuje Wittgenstein: „Byli jsme drženi v zajetí určitým obrazem. A z toho jsme se nemohli vymanit, nebot' tkvěl v naší řeči, a ta jako by nám ho jen neúprosně opakovala..." (1998, § 115, s. 65). I my jsme chyceni v zajetí obrazu a řeči, které tento obraz neustále reprodukují. Oním základním skriptem, na základě kterého podvědomě jednáme, je přesvědčení, že znalost vzniká a je uchovávána uvnitř subjektu a teprve posléze je tato znalost sdílena, konfrontována a upravována v prostoru mezi subjekty. Jinými slovy Castillo by svůj paradox mohl vyřešit pouze tím, že by opustil tradiční představu 
znalostí jako proměnných, které jsou získávány i udržovány uvnitř subjektu a teprve posléze použity ve vnějším prostoru.

K takovému pojetí se blíží některé novější koncepce TZ. Např. Connell, Klein a Powell (2003) navrhují kybernetický model znalostí, podle kterého jsou tacitní znalosti součástí systému, který zahrnuje jak mysl subjektu, tak vnější prostředí; jednání subjektu je kontrolováno a řízeno zpětnými vazbami mezi subjektem a prostředím (srov. Connell, Klein, \& Powell, 2003, s. 147). ${ }^{5}$ Abychom však dokázali docenit takový př́istup a navíc abychom nezůstali pouze $\mathrm{v}$ deklarativní rovině, jak se to stalo zmíněným autorům, musíme $\mathrm{s}$ naším obrazem situace udělat daleko více. Chceme-li proměnit porozumění znalosti a TZ, nemůže se jednat pouze o novou definici jednoho či dvou pojmů. Nový význam musí už mít své „místo“ předem připravené, jak nás upozornil Wittgenstein, jinak by nebyl ani rozlišen od celkového pozadí významů, ani by mu nebylo náležitě porozuměno (srov. 1998, §§ 253-257, s. 114-116). Jestliže se objevilo nové pojetí znalosti a TZ (byt' zatím převážně jen v deklarativní rovině), pak tomu tak může být pouze proto, že se zde již více jak 150 let prosazuje alternativní styl myšlení, který se vymezuje vůči stylu tradičnímu. „Tradiční myšlení" budeme odtud dále nazývat „tradiční paradigma“ a srovnávat jej s „paradigmatem alternativním“.

\section{Funkcionalistický přístup k pojetí znalosti}

Abychom lépe uchopili zdánlivou „nevymezitelnost“ pojmu TZ, pokusili jsme se texty autorů, kteří o TZ píší, konfrontovat s dlouhodobějším kontextem jednoho z významných progresivních proudů $\mathrm{v}$ psychologii a pedagogice. Tímto proudem je funkcionalismus a my jsme brali v úvahu především koncepce J. Deweyho, G. H. Meada, L. S. Vygotského a J. Piageta. Současní autoři, kteří v 80. a 90. letech 20. stol. ve svých textech používají TZ jako klíčový termín, jej stále více zbavují jeho dynamicky vztahového charakteru (jaký původně měl u M. Polanyiho), nebot' jej pod vlivem tradičního paradigmatu substantivizují. To znamená, že podceňují primárnost vztahových a dynamických prvků inteligence, poznání a znalosti a vrací se $\mathrm{k}$ východiskům tradičního myšlení. Podle tradičního paradigmatu pojmy denotují existující, jasně ohraničené části biologické, fyzické, psychologické nebo sociální reality. Tyto

\footnotetext{
Harré a Gillett (2001, s. 49) podobně upozorňují, že „musíme sa naučit’ vnímat’ mysel' ako priesečník širokého okruhu štrukturujúcich vplyvov, ktorých povaha sa dá postihnút' iba v širšom rámci než je ten, ktorý nám poskytuje štúdium individuálných organizmov“.
} 
části tak sice mohou mít vztahy k jiným částem, nicméně jejich podstata je předem dána a tyto vztahy nemohou podstatu ovlivnit. Jestliže jsou tedy části náležitě poznány, je znalost stejně jasně ohraničená, a tedy i lehce explikovatelná jako jejich denotáty. Po své substantivizaci je i význam tacitních znalostí statický. A tak se TZ stávají zvláštním hybridem, se kterým si nejsme $\mathrm{s}$ to poradit. Napřr z jednání zkušeného učitele cítíme, že se $\mathrm{v}$ jeho jednání odráží nějaká znalost, ale ani učitel, ani pozorovatelé či výzkumníci nedokáží tuto skrytou, zamlčenou znalost explikovat. Taková znalost není diskrétní, není jednoduše oddělitelná od svého okolí, a proto jí nedokážeme přiřadit náležitý a jasný význam. S tím také souvisí, že ji nedokážeme náležitě komunikovat a kodifikovat.

Alternativní paradigma převrátilo primát $\mathrm{v}$ dvojici podstata - vztah ve prospěch vztahů. V dílech výše zmíněných autorů (Dewey, Mead, Vygotskij, Piaget), ale i autorů dalších najdeme zcela odlišný přístup k realitě. Primární jsou vztahy a teprve ony utvářejí časově omezené, významově jen dočasně vymezené části. Hlavním prostředkem pochopení reality kolem nás se stávají funkce, které dané vztahy plní. Z nich evolučně a epistemologicky nejdůležitější funkcí je nacházení rovnováhy mezi jedincem a jeho okolím. Pro účely této části textu se zde spokojíme pouze s orientačním vymezením tohoto intelektuálního pohybu a učiníme tak prostřednictvím děl dvou autorů - Deweyho a Piageta. Výběrem časového rozmezí, $v$ němž se budeme $\mathrm{v}$ následujících odstavcích pohybovat (90. léta 19. století až 60. léta 20. století), mimo jiné také naznačujeme, že alternativní paradigma se vždy prosazuje mnoho desítek (někdy i stovek) let, a je proto zcela běžné, že přežívá a postupně sílí vedle paradigmatu starého. ${ }^{6}$

Dewey již roku 1896 napsal text The reflex arc conception in psychology (Dewey, 1992, ew.5: 96-110). $\mathrm{V}$ tomto textu se poprvé zmiňuje o primár-

6 To často vede $\mathrm{k}$ situaci, $\mathrm{v}$ níž se nachází i současná pedagogika. Jednotlivé vědecké obory i výzkumné týmy čerpají z přístupů obou paradigmat, a tak jsou jejich terminologické systémy a jejich vědecké poznatky předem řízeny nepřiměřenými očekáváními, která vedou k nejasnostem a vnitřním nekonzistencím výsledků, popř. $\mathrm{k}$ jejich malé využitelnosti v praxi.

7 Jednalo se o jeden z prvních mezníků signalizujících přechod od psychologie introspektivního př́stupu a psychologie založené na mechanickém principu stimulus-reakce $\mathrm{k}$ psychologii funkcionální a vztahové. V roce 1942 byl vybranými sedmdesáti vědci - psychology vyhodnocen jako nejdůležitější text uveřejněný v časopise The Psychological Review za 49 let jeho trvání (srov. Hickman \& Alexander, 1998, s. ix). (Zápis odkazu na Deweyho dílo je přizpůsoben standardizovanému odkazování na jeho Sebrané spisy. „Ew“ zde znamená dílo raného období - na jiném místě níže „lw“ dílo pozdního období - číslice po tečce číslo svazku, číselné vymezení po dvojtečce odkazuje ke stránkovému rozsahu v daném svazku.) 
nosti vztahu mezi jedincem a prostředím, jež se projevuje v tzv. „smyslově pohybovém okruhu", který překračuje hranice mezi jedincem a prostředím (tamtéž, 96-97). 0 téměř 40 let později tuto myšlenku Dewey rozpracovává v textu Logic: The theory of inquiry, kde píše o sjednoceném prostředí, jehož podstatou je skutečnost, že energie ${ }^{8}$ organismu a energie prostředí na sebe navzájem působí tak, aby nalezly vztah rovnováhy, a tím ustavily podobu sjednoceného pole. ${ }^{9}$ Aspekty sil prostředí jsou podmínkou proměny organismu a aspekty sil organismu jsou podmínkou proměny prostředí (srov. Dewey, 1992, lw.12: 32-33). Slovem aspekt zde naznačujeme, že organismus a prostředí nejsou entity, které lze chápat odděleně jednu od druhé. Aspekty prostředí utvářejí a ovlivňují podobu organismu a organismus utváří a proměňuje prostředí. Navzájem se prostupují. Z hlediska psychologie a pedagogiky to znamená, že jedinec a prostředí jsou nedílné aspekty jedné situované reality, které od sebe odlišujeme pouze v reflexi. ${ }^{10}$

V textech z 60. let 20. století, jimiž Piagetovo dílo vrcholí, se setkáváme s podobnými představami, se kterými se můžeme střetnout v Deweyho díle. Piagetova stopa je v evropské psychologii a pedagogice podstatně silnější, nicméně i přijetí jeho díla je často zjednodušující. Mnozí opomíjí ontologické a epistemologické předpoklady, na kterých jsou jeho myšlenky postaveny. Např. i známá Piagetova čtyři stádia vývoje lidské inteligence se stanou př́iliš plochá a tajemná, jestliže nejsou vzata v potaz jeho základní východiska. Právě ona činí Piagetovu teorii konzistentní. Inteligence není podle Piageta schopností oddělenou od nižších forem poznávání (vnímání, zvyk, senzomotorické adaptace). Inteligencí rozumí restrukturování vnějšího i vnitřního prostředí poznávajícího. Restrukturování se uskutečňuje prostřednictvím

8 Slovo „energie“ zde používáme v širokém metaforickém smyslu. Znamená zde materiál fyzický, chemický, biologický, psychický atd., který je na jedné straně vybaven schopností ovlivňovat své okolí, ale na straně druhé není předem pevně strukturován a je otevřen dalšímu formování. Inspirujeme se zde užitím tohoto slova G. A. Kellym (srov. 2003, s. 24-26, 378) a bereme vážně jeho upozornění, že slovo „energie“ nemůžeme vnímat jako pojem, jenž má substanční charakter, který funguje jako stimulus v kauzálním řetězci stimulus-reakce (např. jako ve Freudově použití termínů „pud“ či „energie“). Tento pojem zde naznačuje pohyb, tekutost, kontinuitu zkušenostního proudu, proměnu funkcionálních hranic atd. K tomu viz také Šíp (2011, s. 23, pozn. 7).

9 Odtud dále budeme tuto představu označovat termínem „sjednocené pole“ z toho důvodu, že ji tak bude možné snadněji propojit s představami "sebeustavujících se polí“, jaké známe z výsledků současných výzkumů ve fyzice, biologii, genetice, ekologii a v dalších oborech.

10 K detailnějšímu výkladu Deweyho filozofie a psychologie a do určité míry i pedagogiky viz Šíp (2014). 
procesů asimilace a akomodace, díky kterým inteligence dosahuje „nejpružnější a zároveň nejtrvalejší rovnováhu chování" (Piaget, 1966, s. 14). Asimilace a akomodace vyjadřují podstatu poznání jako souvislého a vzájemného vylad'ování jedince a jeho prostředí. Asimilací je rozuměno působení organismu na okolní předměty, prostřednictvím kterého organismus mění prostředí či své vnitřní konstrukty nebo obojí. Akomodací jsou potom změny, které vznikají vlivem tlaku prostředí a vedou ke změnám na úrovni organismu. Asimilace a akomodace jsou dvěma aspekty jednoho dynamického vztahu, pomocí kterých dochází k nalézání rovnováhy v kontaktu mezi organismem a prostředím (srov. Piaget, 1966, s. 9-21, zejména s. 11-15). ${ }^{11}$

U obou autorů je zřejmý důraz na rovnováhu, která vzniká proměňováním jak energií jedince, tak energií prostředí. V tradičním myšlení se předpokládá, že pravé poznání není ničím motivované a nemá žádné předpoklady, které by zamezily poznat skutečnost takovou, jaká je nezávisle na našich potřebách, úrovni našeho poznání a našeho předporozumění. Ovšem $v$ alternativním paradigmatu v takto „bezpředpokladové“ poznání již nelze věřit. Funkcionální propojenost mezi prostředím a jedincem je natolik silná, že jedno lze oddělovat od druhého pouze $\mathrm{v}$ teoretické reflexi, která je vždy již něčím motivována a je již předem založena na nějakých předporozuměních. Neměli bychom tedy kolem nás vidět prostor, který se skládá ze zcela oddělených „částí“ - organismus a prostředí. Měli bychom realitu vnímat jako různá pole, jež ustavují jednotlivé, časově více či méně omezené struktury energií, přičemž tak činí za účelem dosažení rovnováhy. Rovnováha je základní podmínkou zachování života a zvyšování jeho kvality.

V tomto systému je znalost strukturou proměny energií, která prostřednictvím fyzických či psychických změn vede k dočasné rovnováze. Znalost má proto nejen povahu poznatku (schématu či reprezentace), ale ještě i dalších dimenzí. Poznatek má časově omezený charakter, je diskrétní (jasně odlišitel-

11 Výrazy „asimilace“ (assimilation), „akomodace“ (accommodation), „adaptace“ (adaptation) používal již J. Dewey na konci 19. století a využíval je až do poloviny 30. let. Je možné, že se Piaget nechal Deweyem inspirovat. Nicméně Dewey je používal nikoli jako komplementární pojmy pojmenovávající jednu skutečnost nahlíženou ze dvou úhlů pohledu jako Piaget. Někdy toto použití šlo zcela proti významům, které jim přisoudil Piaget. Např. v Qualitative Thought, mimochodem jednom z podstatných textů k porozumění Deweyho pozdního díla, je tento pojem použit zcela opačně (srov. Dewey, 1992, lw.5: 261). Dewey však na konci 30. let a v 1. polovině 40. let vytvořil terminologii, která je nosná a konzistentnější než Piagetova, a proto ji zde využíváme. 
ný od poznatků ostatních) a pojmenovává diskrétní předměty reality. ${ }^{12} \mathrm{Zna}$ lost je však vedle poznatku zároveň $i$ změnou, k níž došlo jejím uplatněním ve sjednoceném poli. Je kontinuální ve dvou významech. Je kontinuální ve smyslu materiálu, z něhož je změna utvořena - současná změna v sobě jako svůj světelný závoj nese stopy desítek a stovek změn předcházejících, které tvoří významný informační potenciál pro pochopení podstaty dané znalosti. Stejně tak je kontinuální ve smyslu časovém - všechny dílčí proměny uskutečněné $\mathrm{v}$ době od počátku změny po její konec a jejich časové návaznosti jsou také její součásti. Každá znalost v sobě nese stopy stovek změn, které vedly k jejímu ustavení. Proto počet a kvalita informací, jež v sobě každá jednotlivá znalost nese, přesahují možnosti vědomého uchopení jednotlivcem. Proto $v$ tomto pojetí již nelze chápat znalost jako vědomý diskrétní adekvátní obraz, jenž si utváříme o vnějším světě a jenž budeme níže nazývat „poznatkem“. A proto, když z tohoto úhlu pohledu budeme přemýšlet o poznání (jako o aktech nabývání znalostí), musíme do něj včlenit to, co bylo tradičně z poznání vytčeno a vyloučeno - materiální působení, nevědomé reakce, dispozice, sedimentace zvyku, jednání řízené zvykem, senzomotorické přizpůsobení, jen částečně kontrolované jednání atd. Tím také musíme opustit představu, že poznání je pouze vědomím ohraničený kognitivní akt nabývání poznatkü.

V takovémto pohledu na svět bychom TZ neměli hledat v subjektivní zkušenosti či uvnitř subjektu, jak to činí drtivá většina autorů píšících o TZ. Naopak bychom je měli hledat (a tedy i zkoumat) v „poli ovlivnění“. Polem ovlivnění budeme rozumět velkou část jedince (organismu) a zároveň jeho - podle kontextu různě velké - okolí. Toto pole je místem výše zmíněného vylad'ování (v Piagetově dikci: místem asimilace a akomodace). Pojem pole je zde důležitý ze dvou důvodů. Zaprvé jde přesně o ono místo, kde má dojít k „sjednocení“, $\mathrm{k}$ nalezení dočasné rovnováhy. A zadruhé $v$ tomto poli je nutné strukturu znalosti i její tacitní dimenzi hledat jak ve změnách uvnitř organismu (neuronální, hormonální, chemické, emocionální či evaluační a hodnotící procesy, fenomenologicky ustavující se významy poznatků, představ, preskripcí atd.), tak ve vnějším okolí (ve změnách, které jsou uplatněním znalosti uvedeny $\mathrm{v}$ existenci). Je tomu tak proto, že znalosti již nemůžeme chápat pouze jako

12 Samozřejmě se jedná pouze o zdánlivě „diskrétní“ předměty. Jsme stále v rámci alternativního paradigmatu, v němž diskrétní předměty jsou pouze dočasné platformy energií, nejsou ontologicky oddělené. Tím máme na mysli, že části, které od sebe hranice oddělují, jsou na sobě navzájem závislé. 
„poznatek“ - tedy jako mentální reprezentaci (k odlišení poznatku a znalosti viz 4. a 5. část textu), ale jako strukturu všech změn jak uvnitř, tak v jisté části okolí vně poznávajícího organismu.

\section{Tacitní znalost jako jeden z projevů váhání mezi dvěma paradigmaty}

Přestože alternativní paradigma sedimentuje a prosazuje se více jak 150 let,, ${ }^{13}$ vztahovost, která je jeho podstatou, je pro nás těžko pochopitelná, a proto se raději vracíme do mechanického obrazu světa oddělených předmětů. Jednou nohou tedy stojíme $\mathrm{v}$ tradičním, druhou $\mathrm{v}$ alternativním paradigmatu. Již nejsme schopni se vrátit zpět, ale zatím nemáme dost odvahy a intelektuální přesvědčivosti, abychom začali důsledně promýšlet svět prostřednictvím paradigmatu alternativního. Tak se nám naše teorie stávají příliš jednoduché ve svém aditivním charakteru. Vyjmenováváme jednotlivé vlastnosti zkoumaných jevů bez schopnosti je dynamicky a funkcionálně integrovat. $V$ podstatě podléháme principu substantivizace, k němuž nás vede předporozumění tradičního paradigmatu. Vyjmenovávání a vyčleňování jednotlivých vlastností a jejich proměna na diskrétní „části“ nám zabraňuje porozumět světu takovému, jaký ve své vztahovosti a dynamičnosti skutečně je.

Tuto skutečnost si můžeme dokumentovat na pokusech znalost definovat a explikovat novým způsobem. Zmíněné pokusy většinou sklouznou k tomu, že jsou prŕ́davně vyjmenovány různé typy znalostí a znalost je pak velmi zběžně popsána právě jen z hlediska jednoho zmíněného typu bez náležitých vztahů $\mathrm{k}$ „typům“ ostatním. Na základě průzkumu odborné literatury detekoval Janík (2005, s. 21-23) třináct (!) typů znalostí: „deklarativní“, „procedurální“, „kontextuální“, „teoretické“, „praktické“, „osobní“, „kolektivní“, „zkušenostní“, „inertní“, „implicitní“, „explicitní“, „profesní“, „expertní“. Takovým portfoliem typů je sice vyhověno faktu, že znalost nemůže být pouze poznatek (reprezentace), který vznikl v subjektu poznání, nebot' se objevují znalosti vázané na procesy, vázané na komunity, vázané na praxi atd. Ovšem o znalosti celkově se nedovídáme téměř nic, a tak nás takové teorie matou. Jsou přesto využitelné a potřebné za té podmínky, že člověk, který tyto teorie používá, je používá

13 Jako předznamenání tohoto paradigmatu bychom měli vnímat již objev tvůrčí funkce času v hegelovské filozofii, za plnohodnotnou součást tohoto paradigmatu musíme považovat Darwinův evolucionistický pohled na utváření živočišných druhů, který jako první systematicky překročil představu věčných podstat věcí kolem nás. 
jako analytický nástroj, který mu má pomoci odlišit jednotlivé aspekty dané situace. $V$ tomto př́padě jednotlivé aspekty znalosti. Jestliže však přistupujeme k teorii jako k tomu, co odhaluje, kopíruje „pravé kontury světa“ - a právě v takovém obrazu nás tradiční paradigma vychovává a učí nás myslet - pak promítáme heuristický nástroj do reality a realitu pak nahlížíme skrze naše teorie. Když tímto způsobem zaměňujeme skutečnost za teorii, vede nás to $\mathrm{k}$ tomu, že teorie a praktické jednání spolu přestávají souviset. Po určité době se takové teorie zdají být zbytečné a dochází k odloučení praxe a teorie. Např. v tomto př́padě má praktik sice po ruce portfolio typů, které vypadají jako zvláštní druhy znalostí, ale v realitě nenachází ani jediný typ oddělený. Teorie ho neučí vnímat jednotlivé „typy“ jako dynamické aspekty jedné skutečnosti, protože typy v teorii stojí v lepším případě vedle sebe, $\mathrm{v}$ horším se navzájem vylučují. Význam takové teorie je pro praktika nulový a on se raději spolehne na svoji lépe či hůře reflektovanou zkušenost.

Tento aditivní přístup vede také k tomu, že vedle nepoužitelnosti teorií v praxi si ještě vytváríme bariéry, které brání výzkumu v jeho náležitém a plodném průběhu. To je př́ípad i TZ. Ta je ve výše zmíněném výčtu definována přesně tím způsobem, který jsme v předcházejících částech hodnotili jako principiálně nefunkční a k výzkumu zcela nevhodný: Implicitní (tacitní) znalosti jsou ty, „které subjekt vlastní, ale není schopen je verbalizovat" (Janík, 2005, s. 22; zvýraznění přidáno autory). Zbytky tradičního paradigmatu nám zevnitř našeho přístupu zabraňují myslet a zkoumat realitu přiměřenějším způsobem. Abychom byli schopni rozumět znalosti a TZ funkčním způsobem, musíme je pochopit plně $\mathrm{v}$ řádu alternativního paradigmatu. Musíme se zbavit naší tendence vidět kolem nás svět oddělených objektů stejně jako naše poznání chápat jako oddělené, byt' na sebe navazující fáze kognitivního jednání. Světu, v němž žijeme, podobně jako našemu poznání musíme porozumět jako spojitému poli vzájemných ovlivnění, v němž jednotlivé „části“, které vymezujeme, jsou pouze aspekty nedílného kontinua. Tato skutečnost vede mimo jiné i $\mathrm{k}$ potřebě nově vymezit významnou část pedagogické terminologie.

Celá tato část a v podstatě celý text jsou založeny na netradičním pojetí poznání. V modernější době je formulována na konci 19. a během 1. poloviny 20. století v pragmatismu. Tato koncepce však není pouhou postmoderní či poststrukturalistickou korekcí tradičního pojetí. Je zcela svébytná a přesvědčivá, protože se vyhýbá všem slabým místům většiny reprezetacionalistic- 
kých (korespondenčních) či idealistických teorií pravdy a poznání. V této teorii není poznání rozuměno jako hledání korespondence mezi našimi teoriemi a poznatky a př́slušnými částmi „pravého světa“ (tradiční pojetí), ani jako vyjednávání výhodné konstrukce (postmodernismus, poststrukturalismus). Je zde chápána jako řešení problémů. Kritéria, zda byl problém vyřešen, či nikoli, jsou konstruována na základě našeho dosavadního poznání a zároveň podmiňována skutečností, zda se blížíme stavu, v němž jsme schopni dlouhodobě přežívat a harmonizovat naše potřeby s potřebami a možnostmi našeho okolí. „Sjednocené pole“ je metaforické vyjádření této změny porozumění. V následujících částech budeme tyto skutečnosti ještě hlouběji představovat. K detailnější analýze se však čtenář bude muset obrátit k následujícím zdrojům (Dewey, 1992, mw.8: 14-82, lw.12; Šíp, 2014). Ukážeme, jaké významy a proč jsou přisuzovány některým pedagogickým pojmům v tradičním paradigmatu a jak musejí být tyto významy alternovány, jestliže budeme důsledně vycházet $\mathrm{z}$ paradigmatu nového. Vzhledem $\mathrm{k}$ omezenému rozsahu této studie se však budeme moci věnovat pouze pojmům poznatek, znalost, jednání, subjektivní a objektivní.

\section{Tradiční paradigma - znalost / poznatek, subjektivní / intersubjektivní}

Než se pustíme do popisu tradičního paradigmatu, musíme učinit jednu historiografickou poznámku. Jak bude zřejmé níže, je zde tradiční paradigma pochopeno jako paradigma substanční - tzn. takové, které předem vychází z přesvědčení, že objekty jsou vnímány jako od sebe oddělené díky tomu, že každý má svoji neměnnou substanci či podstatu. $\mathrm{V}$ historii filozofie 17.-19. století se objevily nesubstanční přístupy - z nejúspěšnějších jmenujme např. spinozovský, leibnizovský či hegelovský. Nicméně, i když měly velký ohlas na poli filozofie a na poli vědy inspirovaly některá řešení dílčích problémů, paradigma raně moderní vědy je zakotveno pouze v substančním př́stupu k realitě.

Obě dvojice pojmů zmíněných v názvu této části jsou v tradičním paradigmatu svázány s představou pevné hranice mezi jedincem (objektem) a okolím. Není tím míněna pouze tělesná hranice, ale také hranice ontologická. Tím máme na mysli, že v tradičním paradigmatu je jedinec (objekt) ontologicky předem určen svojí podstatou (substancí) a vztahy s okolím jsou až sekundární záležitostí. 
Tradiční paradigma se počínalo rodit na přelomu renesance a novověku. V té době se objevila představa oddělených objektů (lidí, stromů, kamenů atd.), které mají svoje vnitřní „pevné jádro“ - tzn. ony podstaty. ${ }^{14} \mathrm{Na}$ počátku 17. století se dále utváří představa vnitřního prostoru - (viz např. Descartes, 2003, především s. 27-35, 65-80), který byl později nazván bud' tradičně „duše“, či nově „mysl“. Od té doby je vnější svět v jistém smyslu produktem duše/mysli, protože prostřednictvím svých kognitivních schopností uvnitř sebe mysl reprodukuje vnější svět - utváří reprezentace. Takový obrázek vedl $\mathrm{k}$ představě, že lidské tělo je poznávací aparát, který je spojen s myslí (ke stručné historii této konstrukce viz Rorty, 2012, s. 51-72). Díky části tohoto aparátu (smyslovým receptorům) je člověk schopen snímat vzruchy z vnějšího okolí, přenášet je do mysli (později mozku), kde jsou zpracovávány a kde se z nich utvářejí mentální obrazy a verbální zpodobnění těchto obrazů. Tyto obrazy a verbální vyjádření se $\mathrm{v}$ moderní epistemologii nazývají reprezentace, nebot' údajně reprezentují - bud' adekvátně, či neadekvátně vnější realitu. K pravdivému poznání vnějšího světa dochází tehdy, když je reprezentace (obraz, propozice, teorie) v souladu s příslušnou částí vnějšího světa - když jí adekvátně odpovídá, koresponduje s ní (k historii této konstrukce viz Rorty, 2012, s. 129-202).

Jaké důsledky má toto paradigma na konstrukci pojmu znalost? Především znalostv tomto pojetí splývá s poznatkem (valternativním jebudeme důsledně rozlišovat). Poznatek je reprezentací příslušného výseku vnějšího světa. Na konstrukci znalosti/poznatku se vnější svět podílí pouze zprostředkovaně, prostřednictvím informací, které o vnějších objektech, jejich chování a jejich vztazích získávají receptory na povrchu našeho těla. Znalost je tak utvářena pouze $\mathrm{z}$ „materiálu našeho já“. Utváří se $\mathrm{v}$ celém našem těle - receptory přijímají informace, nervové spoje prostupující celé tělo tyto informace sbírají a vedou, mozek je zpracovává a využívá, mysl je schopna si je uvědomovat a vědomě s nimi manipulovat. Ovšem hranice těla je $v$ tomto paradigmatu hranicí, kterou znalost nemůže prestoupit. Znalost/poznatek je schopna/en dostat se za tuto hranici pouze jediným způsobem, a tím je jednání. Podle tradičního paradigmatu však jednání znalost neutvář́, znalost/poznatek se utvárrí uvnitř těla. Jestliže tuto základní vlastnost - schopnost náležité reprezentace - od znalosti oddělíme, nezbývá v tradičním paradigmatu

14 K vyjasnění této teze a tezí následujících a k vysvětlení přechodu od anticko-scholastického paradigmatu myšlení k paradigmatu raně modernímu (zde jej nazýváme „tradiční”) viz Šíp (2012). 
jakýkoli prostor pro další kognitivní vlastnosti a procesy, které by mohly tvořit tu část, jež odlišuje znalost od poznatku. Znalost se vyčerpává tím, co je uvnitř jedince poznáno jako adekvátní reprezentace vnější reality. Je-li něco, co přebývá, je to pouze neadekvátní reprezentace - a tedy ne-znalost. Právě tato jednostrannost raně moderního pojetí znalosti vedla k nespokojenosti a hledání nových vymezení znalosti. Jestliže však tuto nespokojenost řídí východiska tradičního paradigmatu, pak se „nová definice“ znalosti bude vyčerpávat pouze substantivizováním jednotlivých aspektů, přičemž celé úsilí tak vychází naprázdno.

Neprostupnou hranicí objektu, která striktně odděluje objekt od jeho okolí, jsou definovány a ovlivňovány všechny významné dvojice pojmů. My se zde ještě budeme věnovat další centrální dvojici - subjektivita vs. intersubjektivita. Slovo subjekt ve významu „poznávající a myslící osoba“ má své kořeny na počátku rané moderny (17. století). Právě v tomto pojmu můžeme shledat největší rozporuplnost tradičního paradigmatu. Veškeré poznání se utváří uvnitř jedince (subjektu), z vnějšího světa do jeho těla proudí pouhé vzruchy či data. Přesto je takové poznání neadekvátní, dokud není objektivizováno, například nalezením korespondence mezi reprezentací či teorií a skutečností. $\mathrm{Na}$ začátku rané moderny byl intersubjektivní prostor pouhým médiem přenášených informací a místem jednání - byl tedy čímsi, co nebylo pro teorii poznání důležité. Problém ovšem nastal ve chvíli, kdy samotná věda začala tematizovat skutečnost, že jednotlivé subjekty nemají přístup k objektivní realitě, jsou od ní z principu odděleny. Proto i v tradičním paradigmatu intersubjektivní prostor postupně nabývá na významu - stává se prostorem vyjednávání významů a prostorem odhalování pravdivosti znalostí/poznatků. Přesto je intersubjektivita pro tradiční paradigma podvratnou představou, protože do něj zpětně zavádí význam vztahů. Jak uvidíme v př́íší části textu, byla to právě intersubjektivita, která postupně rozleptala ideu na sobě nezávislých, oddělených subjektů a ideu jejich primátu v procesu poznávání.

\section{Alternativní paradigma - znalost/poznatek, subjektivní/intersubjektivní}

Alternativní paradigma pracuje s představou nadřazenosti vztahů nad částmi reality. Primární je pro něj sjednocené pole, jehož základní charakteristikou je dosahování dočasné rovnováhy mezi energiemi organismu či objektu 
a energiemi prostředí. ${ }^{15}$ Zásadní pro pochopení primátu pole před jeho aspekty byly objevy mnoha disciplín, na základě kterých museli vědci uvažovat o formách toho, co je kolem nás, jako o sebe ustavujících se polích, v nichž se utvářejí různě dlouho trvající platformy způsobů existence (atomy, chemické prvky, horniny, organismy, rostliny, společenství atd.). Taková pole můžeme vidět $\mathrm{v}$ kvantové teorii či v současných teoriích rozšířené mysli ${ }^{16}$ či teoriích rozšířené syntézy. ${ }^{17}$ Dosažení sjednocení ovlivňuje podoby obou aspektů - organismu (objektu) i prostředí - a zároveň je toto sjednocení výsledkem kognitivního procesu. Sjednocení je v tomto paradigmatu chápáno jako dosažení znalosti. Naše těla jsou díky neustálému působení prostředí, v němž se nacházejí, přizpůsobena tak, aby poznávala ještě předtím, než jsme schopni si uvědomit, že se nacházíme v kognitivní či komunikativní situaci. Komunikace a významy nejsou vázány pouze na jedince. Je tomu naopak, jedinec je sám sebe schopen vyčlenit ze svého prostředí, utvořit si představu své identity a představu vnějšího prostředí, které je od něho odlišné, právě proto, že je obnovování jednoty pole již v chodu. Obnovování jednoty pole je komunikací, která ustavuje primární významy ještě předtím, než se objeví vědomí a významy sdílené pomocí lidských jazyků. ${ }^{18}$

Ve svém textu Rockwell (2005) na základě souhrnu a konzistentní interpretace výsledků neurofyziologických, neurobiologických a neuropsychologických výzkumů podtrhl funkci mysli jako struktury, která na jedné straně překračuje hranice organismu a na straně druhé je nezbytná pro přežití vyš-

15 V případě, že by slovu „energie“ v tomto místě bylo porozuměno jinak, mohlo by to být zavádějící, a proto ještě jednou upozorňujeme na poznámku č. 8 výše.

16 Extended mind theory vychází $\mathrm{z}$ desítek a stovek výzkumů neurověd, kognitivních věd, neurobiologie. Podle ní mysl nemůžeme vnímat jako něco, co je uzavřeno v lidském těle, protože mysl je spoluutvářena okolím jedince. Části okolí jsou tedy nedílnou součástí mysli, mysl překračuje hranice organismu, rozšiřuje se za ni (k tomu srov. Rowlands, 2004; Rockwell, 2005; Noë, 2009; Menary, 2010).

17 Extended synthesis theory se nově pokouší shrnout výsledky výzkumů především evoluční ekologie, evoluční biologie, evoluční genetiky. Relativně nedávno (80. léta 20. stol.) vědci začali uvažovat o úzkém propojení genetického zápisu s prostředím a z toho vyplývající hluboké provázanosti organismu s jeho prostředím. K tomu srov. Pigliucci \& Müller (2010); Jablonka \& Lamb (2004); Steele, Lindely, \& Blanden (1998).

18 Tento poznatek moderních výzkumů - k tomu např. výzkumy zrcadlových neuronů či emocí jako připravenosti organismu k jednání (Iacoboni, 2008, viz zejména s. 12-155; Rizzolatti \& Sinigaglia, 2008, především s. 139-171; Damasio, 2010, především s. 87-121) - je v naprostém souladu s Meadovou teorií vzniku jáství (Self). V ní již ve 20. letech 20. století Mead popsal primárnost „sjednoceného pole“, aniž by jej tak nazýval. K tomu viz např. (Mead, 1934/1972; Baldwin, 1986). 
ších živočišných druhů: „Místo aby byla mysl vynořující se vlastností mozku“, uzavírá jeden ze svých významných argumentů, „stává se vynořující se vlastností ,pole jednání [behavioral field], které se vlní a fluktuuje v celém nexu prostředí-tělo-mozek“ (Rockwell, 2005, s. 86). V tomto úryvku jsou zachycené další vlastnosti nového pohledu na vztah člověka a prostředí. Vedle skutečnosti, že mozek, tělo a prostředí utváří „sjednocené pole“, které je zdrojem mysli i vědomí a skrze které se dosahuje znalosti, je zde také správně položen důraz na jednání. Jednání je to, co takové pole umožňuje, co jej spoluutváŕí. Proto je pole nutně časovou, procesuální záležitostí neustále otevřenou změnám. Jednání se nezastavuje ani v okamžiku, kdy člověk vědomě „přestane jednat". Sjednocené pole i pole ve fázi sjednocování vždy jedná. S alternativním paradigmatem také úzce souvisí i důraz na kontinuitu mezi nevědomým a vědomým, mezi reakcí či adaptací a inteligentním jednáním. ${ }^{19} \mathrm{~V}$ tradičním paradigmatu tomu tak nebylo, znalost byla vždy vázána na vědomí a racionální rozhodnutí, proto také bylo nutné odlišit chování od jednání (srov. Janík, 2005, s. 27).

Vrátíme-li se k první z našich pojmových dvojic, pak můžeme konstatovat, že znalost není tím, co má subjekt plně ve své moci (tj. mentální reprezentace), ale je tím, co přivádí celé pole do stavu sjednocení. Znalostí je zde míněn kladný výsledek jednání, který započíná již na podvědomé úrovni a vrcholí ve strukturní změně pole ovlivnění (tzn. jak vnitřního, tak vnějšího prostředí organismu). Např. znalost se projevuje už v tom, že emoce, která je spuštěna na základě proměny mozkové krajiny a je mozkem mapována, promění situaci uvnitř těla (organismus začne pocitovat emoci a tento pocit začne spouštět další vyrovnávací mechanismy, např. aktivitu jistých hormonálních center) a zároveň i situaci mimo tělo organismu, nebot' organismus byl „dotlačen“ k určitému jednání (útěk, přeskočení nečekaně se objevivší díry v zemi atd.; Damasio, 2006, s. 131-136). ${ }^{20}$

Znalost je dynamickou strukturou pole, která je podmíněna a uvedena do funkčního stavu jakčástmi, ježpatřík organismu, takčástmi, jež patří prostředí. Znalost proto musíme vnímat jako něco, co přesahuje organismus - v našem případě jedince. Znalost jako dynamická struktura se utváří a projevuje ve třech rovinách:

19 Všichni autoři zmínění v předešlé poznámce upozorňujía také dokládají výsledky empirických výzkumů, že kognitivní akt předchází vědomí a vědomé rozhodování.

20 Tento př́íklad je př́íkladem nevědomé či polovědomé proměny strukturního pole. Samozřejmě proměny vně i uvnitř organismu probíhají i tehdy, když je jednání řízeno zcela vědomě. 
1) Na rovině vnitřních schémat (poznatků či mentálních obrazů doprovázených propozičním výrazem), která potřebujeme, abychom mohli výsledky nastalé struktury a jejích procedur učinit diskrétními, a tak fixovali procesuálnost jednání a mohli podrobit dění reflexi. Tato část je velmi podobná tomu, co tradiční paradigma chápalo jako znalost/poznatek a my jej v minulé části označili termínem poznatek. $\mathrm{Z}$ toho důvodu budeme tuto rovinu nazývat poznatková rovina.

2) Na rovině změn v poli ovlivnění. Znalost je ve své většině tělesná a materiální, prostupuje naši hlavu a tělo a překračuje v jednání do vnějšího prostoru. Znalostí je např. nejen to, jak jsme schopni v proměnlivém prostředí třídy plné žáků pracovat s naší blízkostí a vzdáleností, jak jsme schopni si hlasem a pohledem utvářet prostor jednání, jak jsme schopni intonačně a pohybem reagovat na rychlé změny v naladění skupiny, jak zvládáme naše nevědomé emoce a pocity atd., ale znalostí jsou také změny, které naše jednání do vnější či vnitřní části pole ovlivnění vneslo, popřr které byly do pole vneseny dalšími procesy. $V$ našem případě by takovou změnou bylo, jak jsme pracovali se zasedacím pořádkem třídy, jakou formu výuky jsme zvolili, jakou atmosféru to vyvolalo atd.

3) Na rovině procesủ transformací. Tato rovina se z pohledu výzkumu znalostí ukazuje být klíčovou, nebot' je to rovina, skrze niž člověk k poznání může přistoupit. Na této rovině dochází $\mathrm{k}$ transformaci ve třech fázích.

3A) První fází je transformace roviny 2. na rovinu 1. Např́ílad, když analyzujeme současný stav pole, reflektujeme průběh jednání a změny, k nimž došlo, když odhadujeme, které další jevy musely proběhnout, aby mohlo dojít $\mathrm{k}$ takovým změnám. Abychom s těmito informacemi byli schopni pracovat, proměňujeme je na sérii na sebe navazujících poznatků, na sérii diskrétních informací a mentálních reprezentací.

3B) Ve druhé fázi pozorujeme právě získané poznatky a poměřujeme je s poznatky již dříve uloženými v naší síti přesvědčení. Součást této fáze je utváření konzistentní sítě systému poznatků, v němž se nové poznatky uspořádaně propojí s těmi ze starých, které nebyly vyhodnoceny jako mylné a které proto nebyly vyřazeny. Je to přesně to místo, $k d e s i$ vytváríme osobní predstavy o nás samotných a okolním světě. Tyto představy pak prostřednictvím komunikace můžeme intersubjektivně sdílet a pozměňovat. 
3C) Ve třetí fázi transformujeme 1. rovinu zpět na rovinu 2. Proměňujeme naši poznatkovou bázi, jejíž základní charakteristikou je diskrétnost a rozpojenost, do podoby plánu jednání a očekávaných výsledků. 3. fáze 3. roviny uzavírá kruh poznání a umožňuje reflektivně zpracované poznatky opět převést $\mathrm{v}$ jednání a dosahovat tak vyladění pole.

Zatímco s rovinou 1. lze díky jejímu reprezentačnímu charakteru (poznatek je diskrétní mentální reprezentace) relativně snadno manipulovat, rovina 3. a především rovina 2. této možnosti snadné manipulace unikají. Je tomu tak proto, že jsou procesuální. Jestliže rovinu 2. prostřednictvím 1. fáze roviny 3. převedeme do roviny 1., podaří se nám to díky tomu, že „rozkrájíme“ procesuální prožitkový proud do diskrétních na sebe navazujících kroků. Utvoříme časové řezy, kterými jednání a změny s tímto jednáním spojené rozčleníme a znehybníme a zároveň tyto řezy přizpůsobíme potřebám mentální reprezentace a následné možnosti symbolického vyjádření. Takto zpracované řezy je možné uložit do „archivu mentálních reprezentací“ a „textuálních explikací", ${ }^{\prime \prime}$ je možné je relativně snadno vyjádřit. Je z nich možné poskládat dřivější události, ale jen v nedokonalé formě.

Protože jsme pod vlivem tradičního paradigmatu znalost identifikovali pouze s poznatkovou rovinou (1.), museli jsme nutně odlišit pojem vědomost od pojmu dovednost. Vědomost, byla pro nás oním řezem, který lze jako mentální obraz či pojmové schéma nebo popis postupu uchopit a „skladovat v hlavě“, popřípadě komunikovat prostřednictvím symbolického vyjádření. Dovednost naopak doplňovala statický charakter vědomosti dynamickým prvkem, byla tím, co jsme museli $\mathrm{k}$ řezu přidávat, aby se vědomost proměnila v aktivní složku. $V$ alternativním paradigmatu je vědomost poznatkem, a tedy pouze statickým aspektem znalosti. Není něčím ontologicky odlišným od dynamického aspektu znalosti - tedy od dovednosti. $V$ tradičním paradigmatu jsme často měli za to, že bez vědomosti (poznatku) nemůžeme jednat, dovednost byla tedy příčinně závislá na vědomosti. Ovšem každodenní skutečnost nás běžně přesvědčuje, že $v$ mnoha př́ípadech jednáme a dokonce adekvátně, aniž bychom disponovali vědomým poznatkem. Tato korekce, kterou před nás realita klade, je pro náš další výklad důležitá z několika důvodů:

21 Vědomě se zde vyhýbáme pojmu pamět', protože pamět' tak, jak je artikulovaná od sv. Augustina přes Bergsona, Husserla až po moderní fenomenologizující biologii (jako př́́klad fenomenologizující biologie viz např. Thompson, 2007, či Noë, 2009), je daleko více zaměřena na procesuálnost. Je to právě pamět', která nás upomíná, že s naším „poznáním“ - s rovinou poznatků (1.) - je něco v nepořádku, že rovina poznatků je „necelistvá“, „,bez života“ a jakoby „beze smyslu“. 
(1) reflektuje skutečnost, že vědomí a vědomé jednání tvoří výraznou menšinu v poměru k nevědomému jednání; (2) že nevědomé jednání a další vědomím neregistrované děje vstupují do poznání a jsou součástí znalosti a (3) že právě $\mathrm{v}$ této oblasti bychom měli hledat významnou část té dimenze, kterou budeme nazývat tacitní.

Odlišení vědomosti a dovednosti kombinované s pocitem, že vědomost nevyčerpává pojem znalosti, které můžeme najít v odborné pedagogické literatuře (srov. Janík, 2005, s. 25; Janík, Maňák, \& Knecht, 2009, s. 64; Průcha, Walterová, \& Mareš, 2001, s. 312), je znakem nerozhodného postavení mezi paradigmatem tradičním a alternativním. Tuto rozporuplnost či nedůslednost lze nalézt také ve formulacích relativně zajímavých pojetí znalosti jiných disciplín. Jednu z nich poskytl např. filozof Tondl (parafráze in Janík, 2005, s. 26), podle kterého má znalost svůj objekt, tedy to, o čem znalost pojednává, svůj subjekt, který je vlastníkem či tlumočníkem znalosti, a svoji kvalitu. Problém této představy spočívá především v prvních dvou charakteristikách. Znalost nemá svůj objekt, protože znalostí je celková dynamická struktura, která se objektem stane až ve chvíli, kdy je $\mathrm{v}$ procesu transformace $\mathrm{z}$ roviny dění do roviny poznatků (fáze $3 \mathrm{~A}$ ) proměněna na poznatek (a stává se tak pouze jedním ze schémat roviny 1.). Znalost nemá svůj subjekt - charakteristika znalosti jako toho, co fluktuuje v poli ovlivnění tam a zpět přes hranici mezi jedincem (organismem) a okolím, zamezuje chápat subjekt jako toho, kdo „vlastní" nebo „tlumočí znalost. To, co jedinec může „vlastnit" nebo „tlumočit", je opět pouze poznatek. ${ }^{22}$

Tím se dostáváme k poslednímu termínu, který je zde ve vztahu k alternativnímu paradigmatu nutné zmínit - k intersubjektivitě. Intersubjektivita se ukazuje být nejvýznamnějším prostředím pro utváření znalosti. Protože se v alternativním paradigmatu pojem subjektu téměř vyprázdnil a zůstala $\mathrm{z}$ něho jenom velmi malá část, ${ }^{23}$ měli bychom také přestat užívat slova inter-

22 Tyto skutečnosti se také výrazně promítají do charakteristiky kvality znalosti. Další rozvíjení této myšlenky si ale necháme jako téma nějakého příštího textu.

23 Ve své eseji Mýtus subjektivního Davidson analyzuje, co vlastně z představy subjektu zbude poté, jakmile jej zbavíme raně moderních mýtů, a konstatuje, že z klasického subjektu zbyly pouze dva rysy: 1 . že myšlenky jsou soukromé a 2 . asymetrie mezi tím, jak poznáváme myšlenky své a myšlenky někoho druhého (srov. Davidson, 2004, s. 71). To však neznamená, že by s vyprázdněním pojmu subjekt zanikal jedinec. Individualita a puzení k jednání zde zůstávají, jedinec se nerozpouští v nějakém mystickém Jednu. To, co se změnilo, jsou pouze epistemologická očekávání a předpoklady rané moderny, že subjekt je zdroj poznání a zároveň kontejner na uchovávání znalostí. Zdrojem poznání je stav celého pole, jak stav jedince, tak stav jeho okolí. A znalost poznáním dosažená je uchovávána jak uvnitř jedince, tak vně - tedy na všech třech výše zmíněných rovinách. 
subjektivita a intersubjektivní, a nahradit je např. slovy transakce a transaktiv$n i^{24} \mathrm{Z}$ tohoto transaktivního pohledu bychom měli přestat používat také pojmy subjektivní a objektivní. Tato slova nás totiž opět svádějí k velice zjednodušující představě, že znalost založená na zkušenosti a jednání jedince (subjektivní znalost) je ze své povahy nedokonalá a potřebuje „objektivizovat". Když se však podíváme na tradiční vymezení slova objektivní, pak se př́mo či oklikou dostaneme k formulacím typu: „objektivní znalost je taková, která odpovídá skutečnosti“. Tím se opět dostáváme k paradoxu subjekt-objektového myšlení, který jsme artikulovali v minulé části textu. Znalost založená na zkušenosti a jednání jedince není subjektivní ani objektivní v raně moderním slova smyslu. Vždy je utvářena v poli ovlivnění (není tedy pouze subjektivní) a nikdy nemůže dosáhnout takové objektivity, jak ji definovala moderna - jako více či méně přesné kopie „pravého světa“. Cílem poznání totiž není kopírovat realitu či udělat naprosto adekvátní obrázek reality, ale dosahovat stavu sjednocení. Osobní teorie/znalost může být tedy pouze v daném kontextu účinná či neúčinná, a pokud je neúčinná, pak proto, že nedokáže dosahovat potřebné rovnováhy.

Tato část výkladu alternativního paradigmatu by si zasloužila delší analýzy a vysvětlení, kterým jsme zasvětili samostatný text (Šíp, 2014). Přesto se pokusíme odpovědět alespoň v náznacích na jisté nejasnosti, které tyto formulace vyvolávají. Předně: Nikdo nezpochybňuje, že zde existují rysy světa nezávislé na vůli jednotlivců. Ovšem tyto rysy nepoznáváme způsobem, jak si to představovala celá naše okcidentální tradice - tedy tak, že naše poznatky (mentální reprezentace) jsou schopny tyto rysy zrcadlit. Nemáme nezprostředkovaný př́stup k realitě, a proto také nejsme schopni z principu rozhodnout, zda naše poznatky (či jejich konglomeráty v podobě teorií) adekvátně odpovídají světu, jaký skutečně je. To jediné, co máme po ruce, jsou výsledky našeho jednání, které bylo vedeno našimi poznatky či teoriemi. Vedlo-li jednání k uspokojení, usuzujeme zpětně, že naše poznatky či teorie jsou „pravdivé“. Pravda však v tomto pojetí není hodnotou, kterou přikládáme k propozicím, ale funkčním potvrzením úspěšnosti našeho jednání. Pravda je tedy metaforou toho, „že se blížíme k něčemu opravdovému, významnému“. Tato metafora však nemá nic společného s představou „objektivního poznatku“. Kritéria úspěšnosti si nestanovuje jednotlivec, ale vynucuje si je celá situace. Situace je vyřešena úspěšně, když je pozměněna způsobem, že nerovnováha v poli je vyrovnána. Např. nerovnováhou je, když si žáci mají osvojit postup při řešení

24 Na konci své kariéry se je Dewey snažil ve většině kontextů právě tímto způsobem nahrazovat. 
jistého matematického problému, aby mohli vyřešit další problémy v jiných polích poznatků (ve fyzice, chemii, statistice). Je zde potřeba osvojit si je, ale tato potřeba ještě není naplněna. Když jsme schopni dovést žáky k osvojení si náležitého postupu matematického řešení anebo když žáci přijdou na postup alternativní a ekonomicky a časově stejně výhodný, či ještě výhodnější, došlo k vyrovnání pole, k náležitému řešení situace. Nejsou zde tedy stavy subjektivní poznatek (subjektivní teorie) a objektivní poznatek, ale stav nerovnováhy a vyrovnání. $\mathrm{K}$ detailnějšímu představení teorie poznání $\mathrm{v}$ alternativním paradigmatu viz Šíp (2013, s. 22-37).

To, že má někdo nedokonalé poznání, že se stále nachází ve stavu nerovnováhy, může být zapř́íčiněno např. tím, že poznávající má málo zvědoměnou problematickou situaci, nedokáže ji artikulovat a transformovat tak, aby jeho budoucí jednání dosáhlo rovnováhy pole. Všechny tyto procesy nemají nic společného s objektivitou, tak jak je nejčastěji formulována v epistemologických textech. Proto bychom sousloví „subjektivní teorie učitele“ měli z těchto epistemologických důvodů opustit podobně jako sousloví „vědecká teorie“, přestože tato dichotomická dvojice je standardní výbavou pedagogických teorií (napřs. Janík, 2005, s. 32-34). Věda začíná v té nejaktuálnější a nejsoukromější zkušenosti a nekončí ve vědecké objektivitě, ale ve funkčním završení dynamické struktury.

\section{Závěr: tacitní dimenze znalosti a inspirace pro její výzkum}

Určitou ironií celého našeho textu je skutečnost, že na jeho konci je jisté prožrení, ale nikoli nový svět. Nenabízíme pro výzkum TZ nic, co bychom již dávno neměli „před očima“. Co je nové (respektive, čemu se opět učíme rozumět), je vědomí sounáležitosti všech tří rovin, které utvářejí znalost. Právě v této konfiguraci rovin musíme hledat prostor pro $\mathrm{TZ}$ a důvody $\mathrm{k}$ tomu, proč se musíme zbavit představy substantivizované tacitní znalosti. Prvním krokem, který musíme učinit, je to, že se vrátíme k základní Polanyiho představě: tacitní je pouze specifická dimenze znalosti. Z toho důvodu se přikláníme k označení tacitní dimenze znalosti (dále TDZ), kterou budeme dále používat. ${ }^{25}$

25 Samozřejmě to nepůjde absolutně i díky skutečnosti, že v zadání našeho grantového projektu je použit pojem TZ. Z podobných důvodů nebude snadné obejít pojmy jako subjektivní teorie učitele či vědecký poznatek. 
Druhým krokem je uvědomit si, kde a proč se s TDZ můžeme setkat. Znalost vzniká $v$ poli ovlivnění - tedy jak uvnitř, tak vně poznávajícího. Poznávání je kontinuální proces, a proto i znalost je kontinuální dynamická struktura energií. Struktura prochází spojitou změnou v př́mé úměře tomu, jak se proměňuje situace pole sjednocení od stavu dočasného sjednocení přes stav dočasného rozpadu rovnováhy po nový stav sjednocení. Tato změna prochází všemi rovinami, a proto i roviny jsou v neustálém (byt' někdy téměř nepatrném) proudu dílčích změn. Změny nejsou vázány na vědomí a rozhodnutí. Struktura znalosti prochází změnou ve všech rovinách - dokonce i na rovině 1., kterou je nejvíce možné vědomě kontrolovat - a je nejčastěji vedena reakcí těla a prostředí, adaptací, senzomotorickým či hormonálním přizpůsobením či přizpůsobením emocionálním, které nejsou a často ani nemohou být vědomě kontrolovány. Přesně v těchto momentech bychom měli hledat TDZ např́íc rovinami. Jestliže se zaměříme na jednotlivé roviny, pak nejvíce je TDZ vystavena rovina 2. a 3. Obě roviny pracují s dynamikou a posuny, tedy je velice nesnadné tyto roviny podřídit vědomé kontrole, nebot' vědomá kontrola (nikoli vědomí samo) je svázána s diskrétností a schematizací.

Podíváme-li se na roviny zblízka, nabízejí se dva významné způsoby, jak zkoumat tacitní znalost (resp. TDZ):

A) Můžeme se soustředit na 2. rovinu (roviny změn v poli ovlivnění). TDZ zde může být zkoumána detailním pozorováním průběhu jednání a dění a zhodnocováním změn, které toto jednání přináší. Nemůžeme zde však pracovat tak, jako na rovině 1 . K významům, které $\mathrm{k}$ těmto změnám a dějům budeme přiřazovat jako výzkumníci, nemáme přímý přístup. Budeme je muset fenomenologicky odvozovat $\mathrm{z}$ více či méně obdobných změn a dále komunikovat jejich skutečnou podobu s těmi, kdo budou v této rovině zkoumáni. Výzkumníci i zkoumaní jsou spolupracovníci na odhalování významu znalosti. ${ }^{26}$ Toto vyjednávání významu bude zpětně fungovat jako proces zvědomování TDZ jak výzkumníky, tak studenty (učiteli). I tato skutečnost podtrhuje opuštění raně moderních představ, $v$ nichž to byli vědci, kteří $\mathrm{z}$ titulu své profese a expertnosti měli přístup k pravdivému, adekvátnímu poznání. Kritériem správnosti takto vyjednaných významů pak nebude jejich údajná „objektivita“, ale míra využitelnosti znalosti $v$ dalším jednání. $\mathrm{V}$ našem př́padě bude znakem správnosti to, zda takto

26 Podobně Harré \& Gillett (2001, s. 155) poukazují na to, že humanitní vědy by se měly zabývat nejenom popisem událostí, jejichž součástí je subjekt, ale také tím, jak tyto události interpretuje subjekt. To vyžaduje, aby „výskumník vstúpil so subjektom do dialógu.“ 
zvědoměná TDZ povede $\mathrm{k}$ lepším výsledkům v následné praxi (činnosti) studentů či učitelů.

B) Dalším zdrojem TDZ bude rovina 3. Transformace ve všech třech fázích probíhají často bud' př́liš rychle, nebo bez vědomé kontroly. I zde je možné sledovat vstup (děje a změny) a výstup (poznatky a schémata) a porovnat jejich zřetězení. Ptát se na to, jaké mechanismy mohly vést k těmto propojením, jaké nevědomé motivace, jaké zvykové transformační postupy byly ve hře. I tyto otázky povedou ke zvědomování zmíněných mechanismů, díky kterému bude možné mechanismy částečně korigovat a zjemňovat. I na této rovině budou významy TDZ vyjednávány mezi výzkumníky a praktiky, nebot' výzkumníci nemají k dispozici apriorní etalon toho, jaké transformace jsou „adekvátní“. Opět i zde jsou nutné oba vstupy - výzkumníků a studentů (učitelů) - a zhodnocení, zda je pole po užití dané znalosti blíže či dále k rovnováze.

Z výkladu je zřejmé, že zde nejde o to navrhnout nějaké převratné metody výzkumu. ${ }^{27}$ Podstatný je samotný rámec, který určil, že „tacitno“ je dimenze znalosti, a také skutečnost, že zmíněný rámec zpřesnil, co, proč a jakým způsobem hledáme. K metodám výzkumu TDZ se vrátíme podrobněji v samostatném textu.

\section{Poděkování}

Podobu této verze textu ovlivnily komentáře členů redakce Pedagogické orientace, fundované a inspirativní posudky anonymních recenzentů a diskuse realizované v týmu řešitelů projektu. Autoři děkují všem zmíněným za připomínky a doporučení, na základě kterých mohlo dojít k vyjasnění a celkovému zkvalitnění textu.

\section{Literatura}

Ambrosini, V., \& Bowman, C. (2001). Tacit knowledge: Some suggestions for operationalization. Journal of Management Studies, 38(6), 811-829.

Baldwin, J. D. (1986). Georg Herbert Mead. A unifying theory of sociology. Newbury Park, Beverly Hills, London, \& New Delhi: SAGE Publications.

Castillo, J. (2002). A note on the concept of tacit knowledge. Journal of Management Inquiry, 11(1), 46-57.

27 Konkretizaci metod výzkumu tacitních znalostí prezentujeme v samostatném příspěvku (Švec et al., 2013). 
Connell, N. A. D., Klein, J. H., \& Powell, P. L. (2003). It's tacit knowledge but not as we know it: Redirecting the search for knowledge. Journal of the Operational Research Society, 54(2), 140-152.

Damasio, A. (2006). Descartes' error: Emotion, reason and the human brain. London: Vintage.

Damasio, A. (2010). Self comes to mind. Constructing the conscious brain. New York: Pantheon Books.

Davidson, D. (2004). Mýtus subjektivního. In D. Davidson (Ed.), Subjektivita, intersubjektivita, objektivita (s. 55-71). Praha: Filosofia.

Dewey, J. (1992). The collected works of John Dewey. L. A. Hickman (Ed.). Charlottesville VA: InteLex Corporation.

Descartes, R. (2003). Meditace o první filosofii. Námitky a autorovy odpovědi. Praha: OIKOYMENH.

Harré, R., \& Gillett, G. R. (2001). Diskurz a mysel'. (Úvod do diskurzívnej psychológie). Bratislava: IRIS.

Hickman, L. A., \& Alexander, T. M. (1998). Introduction: Ethics, logic, psychology (s. ix-xii). In L. A. Hickman \& T. M. Alexander (Eds.), The Essential Dewey, Volume 2: Ethics, logic, psychology. Bloomington \& Indianapolis: Indiana University Press.

Iacoboni, M. (2008). Mirroring people. The science of empathy and how we connect with others. New York: Picador.

Jablonka, E., \& Lamb, M. J. (2004). Evolution in four dimensions: Genetic, epigentic, behavioral, and symbolic variations in the history of life. Cambridge (MA) \& London: A Bradford Books \& MIT Press.

Janík, T. (2005). Znalost jako klíčová kategorie učitelského vzdělávání. Brno: Paido.

Janík, T., Maňák, J., \& Knecht, P. (2009). Cíle a obsahy školního vzdělávání a metodologie jejich utváření. Brno: Paido.

Kelly, G. A. (2003). The Personal Construct Psychology. Volume one. A Theory of Personality. London \& New York: Routledge.

Mead, G. H., \& Morris, C. W. (1934/1972). Mind, self, and society. Chicago, London: The University of Chicago Press.

Menary, R. (Ed.). (2010). The extended mind. Cambridge, London: The MIT Press.

Noë, A. (2009). Out of our heads. Why you are not your brain, and other lessons from the biology of consciousness. New York: Hill and Wang.

McAdam, R., Mason, B., \& McCrory, J. (2007). Exploring the dichotomies within the tacit knowledge literature: Towards a proces of tacit knowing in organizations. Journal of Knowledge Management, 11(2), 43-59.

Merleau-Ponty. M. (2004). Viditelné a neviditelné. Praha: OIKOYMENH.

Panahi, S., Watson, J., \& Partridge, H. (2012). Social media and tacit knowledge sharing: Developing a conceptual model. World Academy of Science, Engineering and Technology, 64, 1095-1102.

Piaget, M. (1966). Psychologie inteligence. Praha: SPN.

Pigliucci, M., \& Müller, G. B. (2010). Evolution. The ended synthesis. Cambridge (MA): MIT Press.

Polanyi, M. (1958/1962). Personal knowledge. Chicago: The University of Chicago Press.

Polanyi, M. (1966/1983). The tacit dimension. Gloucester: Peter Smith Publisher.

Průcha, J., Walterová, E., \& Mareš, J. (2001). Pedagogický slovník. Praha: Portál. 
Rizzolatti, G., \& Sinigaglia, C. (2008). Mirrors in the brain. How our minds share actions and emotions. Oxford: Oxford University Press.

Rockwell, W. T. (2005). Neither brain, nor ghost. A nondualist alternative to the mind-brain identity theory. Cambridge, London: The MIT Press.

Rorty, R. (2012). Filosofie a zrcadlo prírody. Praha: Academia.

Rowlands, M. (2004). The body in mind. Understanding cognitive processes. Cambridge: Cambridge University Press.

Stelle, E. J., Lindley, R. A., \& Blanden, R. V. (1998). Lamarck's signature. How retrogenes changing Darwin's natural selection paradigm. Reading (MA): Perseus Books.

Sternberg, R. J. (1999). Epilogue: What do we know about tacit knowledge? Making the tacit become explicit. In R. J. Sternberg \& J. A. Horvath (Eds.), Tacit knowledge in professional practice (s. 231-236). London, New Jersey: Lawrence Erlbaum Associates.

Šíp, R. (2011). Od pevných forem k poli napětí a kontinuity. In M. Hrdá \& R. Šíp (Eds.), Identita v sociálně pedagogickém výzkumu. Pole napětí změn a začlenění (s. 13-26). Brno: MuniPress.

Šíp, R. (2012). Rortyho Zrcadlo konečně v českém střihu. Filosofický časopis, 60(6), 849-867.

Šíp, R. (2013). Nové paradigma vědy, nové paradigma pedagogického výzkumu. In L. Gulová \& Šíp (Eds.) Vybrané výzkumné metody: aplikace v pedagogické praxi (s. 12-37). Praha: Grada.

Šíp, R. (2014). Zkušenost v Deweyho experimentální metafyzice. Radikální překročení subjektobjektové epistemologie. Organon $F$ (přijato k uveřejnění).

Švec, V. (2012a). Tacitní znalosti jako most mezi teorií a praxí v pedagogické přípravě učitelů. Pedagogická orientace, 22(3), 387-403.

Švec, V. (2012b). Sdílení tacitních znalostí ve vzdělávání učitelů jako pohyb od praxe k teorii a zpět. In J. Kohnová, et al., Profesní rozvoj učitelů a cíle školního vzdělávání (s. 99-110). Praha: Univerzita Karlova, Pedagogická fakulta.

Švec, V. et al. (2013, září). Výzkum tacitních znalostí jako východisko zefektivnění pedagogické praxe studentů učitelství. Příspěvek prezentovaný na 21. výroční konferenci České asociace pedagogického výzkumu, Ústí nad Labem.

Thompson, E. (2007). Mind in life: Biology, phenomenology and the science s of mind. Cambridge (MA) \& London: The Belknap Press of Harvard University Press.

Wittgenstein, L. (1998). Filosofická zkoumání. Praha: Filosofia.

\section{Autoři}

Mgr. Radim Šíp, Ph.D., Masarykova univerzita, Pedagogická fakulta, Katedra sociální pedagogiky, Poříčí 31, 60300 Brno, e-mail: sip@ped.muni.cz

prof. PhDr. Vlastimil Švec, CSc., Masarykova univerzita, Pedagogická fakulta, Katedra pedagogiky, Poříčí 31, 60300 Brno, e-mail: svec@ped.muni.cz 


\title{
The concept of tacit knowledge in the paradigm of a unified field
}

\begin{abstract}
The aim of this theoretical study is to clear the concept of tacit knowledge. In the first part of the text, the authors show where the confusion comes from. If we take knowledge as a mental representation we will not, in fact, be able to inquire it. In the second part, an alternative, which has been alive for more than a hundred years, is detected in works on knowledge and knowing by scholars such as Dewey and Piaget. Then, in the third part, the authors depict the hesitation of specialists that could not abandon the old traditional understanding of knowledge (in the study connected with the "paradigm of separated objects") and their need to across it. Thus they stay between the old and the new paradigm (the new one is in the text referred to as the "paradigm of a unified field") and therefore, their theories are very often confusing and unusable in praxis. For better understanding of the two - traditional and alternative paradigms, the authors offer a short introduction to both in the fourth and fifth parts. The study ends by the conclusion that if we are able to understand knowledge not as a representation, but as a dynamic structure of a unified field, we will be able to grasp tacit knowledge as a tacit dimension of the structure and thus we will be able to study it more properly.
\end{abstract}

Keywords: knowledge, tacit knowledge, paradigm of separated objects, paradigm of a unified field, action, dynamic structure

Strouhal, M. (2013). Teorie výchovy. K vybraným problémům a perspektivám jedné pedagogické disciplíny. Praha: Grada.

Kniha je určena učitelům i studentům pedagogiky, učitelství i širší pedagogické veřejnosti. Představuje koncept teorie výchovy jako komplexně založené reflexe zohledňující metodologickou dvojznačnost východisek v myšlení o výchově: východisko filosofie a východisko vědy. Čtenář v textu nalezne rozbor pojmů, bez nichž se teorie výchovy neobejde (diskurs, formativní proces, zájem, autorita, vzdělání, kultura, teorie, praxe aj.). Autor se ptá, zda soudobé pedagogice s jejím důrazem na „akci“ a „zážitek“ nechybí zájem o hlubší reflexi právě těchto základních pojmů. Polemizuje s pokusy chápat výchovu skrze jednoznačné definice, zdůrazňuje antinomickou, kontradiktorickou podstatu procesu výchovy a celé pedagogické teorie. Upozorňuje na nebezpečí skryté v zapomnění na význam ideálu ve výchově a odmítá rezignaci na hledání hodnotících měřítek v době tzv. postmoderny. Smyslem této knihy je přispět k hledání komplexního pojetí výchovné teorie. 